Prepared for the U.S. Department of Energy

under Contract DE-AC05-76RL01830

\title{
Organic Separation Test Results
}

RL Russell

DE Rinehart

RA Peterson

September 2014

\section{Pacific Northwest}

NATIONAL LABORATORY

Proudly Operated by Battelle Since 1965 



\title{
DISCLAIMER
}

This report was prepared as an account of work sponsored by an agency of the United States Government. Neither the United States Government nor any agency thereof, nor Battelle Memorial Institute, nor any of their employees, makes any warranty, express or implied, or assumes any legal liability or responsibility for the accuracy, completeness, or usefulness of any information, apparatus, product, or process disclosed, or represents that its use would not infringe privately owned rights. Reference herein to any specific commercial product, process, or service by trade name, trademark, manufacturer, or otherwise does not necessarily constitute or imply its endorsement, recommendation, or favoring by the United States Government or any agency thereof, or Battelle Memorial Institute. The views and opinions of authors expressed herein do not necessarily state or reflect those of the United States Government or any agency thereof.

\author{
PACIFIC NORTHWEST NATIONAL LABORATORY \\ operated by \\ BATTELLE \\ for the \\ UNITED STATES DEPARTMENT OF ENERGY \\ under Contract DE-AC05-76RL01830
}

Printed in the United States of America

Available to DOE and DOE contractors from the

Office of Scientific and Technical Information,

P.O. Box 62, Oak Ridge, TN 37831-0062;

ph: (865) 576-8401

fax: (865) 576-5728

email: reports@adonis.osti.gov

\author{
Available to the public from the National Technical Information Service \\ 5301 Shawnee Rd., Alexandria, VA 22312 \\ ph: (800) 553-NTIS (6847) \\ email: orders $a$ ntis.gov $<$ http://www.ntis.gov/about/form.aspx $>$ \\ Online ordering: http://www.ntis.gov
}

This document was printed on recycled paper. 

PNNL-23643

RPT-66611-001, Rev. 0

\section{Organic Separation Test Results}

RL Russell

DE Rinehart

RA Peterson

September 2014

Prepared for

the U.S. Department of Energy

under Contract DE-AC05-76RL01830

Pacific Northwest National Laboratory

Richland, Washington 99352 



\section{Acronyms and Abbreviations}

$\begin{array}{ll}\text { D2EHPA } & \text { di (2-ethylhexyl) phosphoric acid } \\ \text { DIW } & \text { deionized water } \\ \text { NPH } & \text { normal paraffin hydrocarbon } \\ \text { PNNL } & \text { Pacific Northwest National Laboratory } \\ \text { PUREX } & \text { Plutonium Uranium Extraction Plant } \\ \text { TBP } & \text { tributyl phosphate } \\ \text { TWINS } & \text { Tank Waste Information Network System } \\ \text { WRPS } & \text { Washington River Protection Solutions } \\ \text { WTP } & \text { Hanford Tank Waste Treatment and Immobilization Plant } \\ \text { WWFTP } & \text { WRPS Waste Form Testing Program }\end{array}$





\section{Contents}

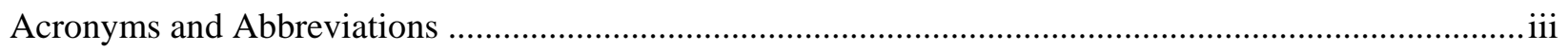

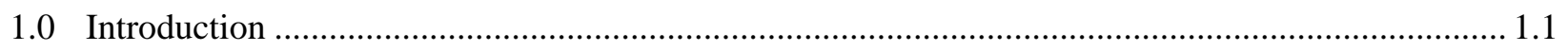

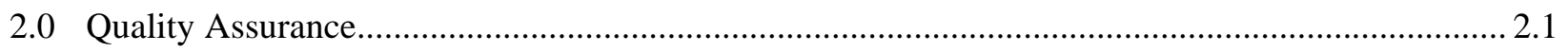

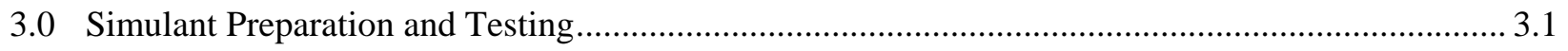

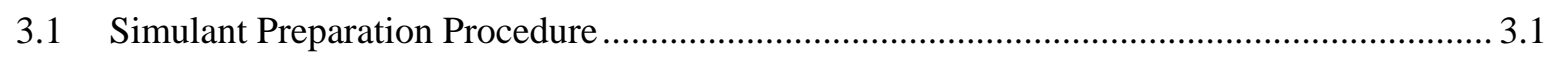

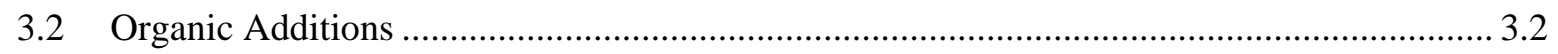

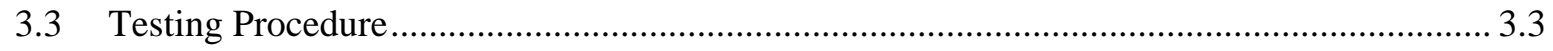

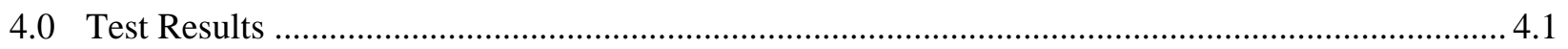

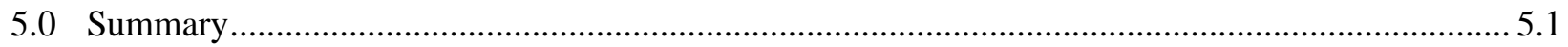

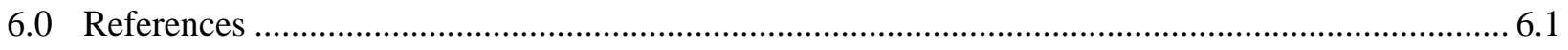

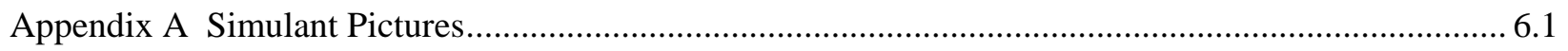

\section{Figures}

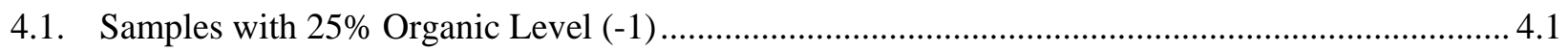

4.2. Samples with 50\% Organic Level (-2A) …............................................................................... 4.1

4.3. Samples with 50\% Organic Level (-2B) Aged at $50^{\circ} \mathrm{C}$ for 7 Days.............................................. 4.2

4.4. Supernate Removed from Simulant Before Organic Added and Aged......................................... 4.2

4.5. Samples with $50 \%$ Organic Level and Supernate Removed (-2C) Aged at $40^{\circ} \mathrm{C}$ for 7 Days and Centrifuged at 4048G for 10 Minutes ................................................................................ 4.3

4.6. Samples with $50 \%$ Organic Level and Supernate Removed (-2C) Aged at $40^{\circ} \mathrm{C}$ for 7 Days and Centrifuged at 1000G for 10 Minutes...

4.7. Each Set of Simulant E 50\% Organic Level Samples Compared in Order Run from Left to Right ................................................................................................................... 4.4

4.8. Simulant A (Test 2C) After Sitting for 3 Weeks Showing Settled Organic Layer ....................... 4.5

4.9. Simulant A Test 2C Freshly Centrifuged ................................................................................... 4.5

\section{Tables}

3.1. Composition of Iron-Rich Sludge Simulant Base .................................................................... 3.1

3.2. Amount of Iron-Rich Sludge, DIW, and Boehmite Added to Simulant Based on 2kg................... 3.1

3.3. Composition of Supernate Simulants .................................................................................... 3.2

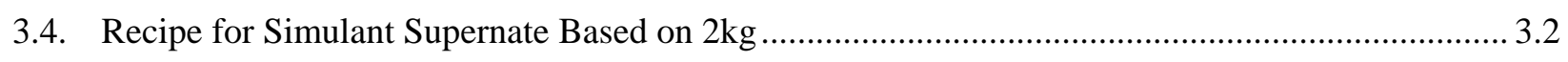

3.5. Baseline Organic Composition................................................................................................ 3.3

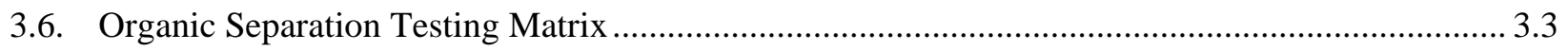





\subsection{Introduction}

Two main types of organic compounds were used in the processing operations at Hanford that sent waste to the Tank Farms: complexants and solvents. Complexants are generally soluble in the tank waste and are not capable of forming a separate layer. Organic solvents and/or complexants include tributyl phosphate (TBP) and di (2-ethylhexyl) phosphoric acid (D2EHPA), which were used with diluents such as normal paraffin hydrocarbon (NPH). These solvents and diluents are immiscible with water and less dense than water, and are thus capable of forming a floating layer (Smalley and Nguyen 2013).

Separable organics have been defined as "those organic compounds of very limited solubility in the bulk waste and that can form a separate liquid phase or layer” (Smalley and Nguyen 2013), and result from three main solvent extraction processes: U Plant Uranium Recovery Process, B Plant Waste Fractionation Process, and Plutonium Uranium Extraction Plant (PUREX) Process. The primary organic solvents associated with tank solids are TBP, D2EHPA, and NPH. There is concern that, while this organic material is bound to the sludge particles as it is stored in the tanks, waste feed delivery activities, specifically transfer pump and mixer pump operations, could cause the organics to form a separated layer in the tank farms feed tank. Therefore, Washington River Protection Solutions (WRPS) is experimentally evaluating the potential of organic solvents separating from the tank solids (sludge) during waste feed delivery activities, specifically the waste mixing and transfer processes. Given the Hanford Tank Waste Treatment and Immobilization Plant (WTP) waste acceptance criterion per the Waste Feed Acceptance Criteria document (24590-WTP-RPT-MGT-11-014) that there is to be "no visible layer" of separable organics in the waste feed, the presence of a visible layer of separable organics would result in the batch being unacceptable to transfer to WTP. The present study is of particular importance to WRPS because of these WTP requirements.

This testing compared five different simulants with these primary organic solvents added. These simulants were tested under various conditions to determine whether the testing activities affected the organic separation in the simulants. 



\subsection{Quality Assurance}

All research and development (R\&D) work at Pacific Northwest Laboratory (PNNL) is performed in accordance with PNNL's Laboratory-level Quality Management Program, which is based on a graded application of NQA-1-2000, Quality Assurance Requirements for Nuclear Facility Applications, to R\&D activities. To ensure that all client quality assurance (QA) expectations were addressed, the QA controls of the WRPS Waste Form Testing Program (WWFTP) QA program were also implemented for this work. The WWFTP QA program consists of the WWFTP Quality Assurance Plan (QA-WWFTP-001) and associated QA-NSLW-numbered procedures that provide detailed instructions for implementing NQA-1 requirements for $R \& D$ work.

The work described in this report was assigned the technology level "Applied Research” and was planned, performed, documented, and reported in accordance with Procedure QA-NSLW-1102, Scientific Investigation for Applied Research, except that the experimental work was initiated before the checklist was completed. However, all procedures were followed throughout testing. All staff members contributing to the work received proper technical and quality assurance training prior to performing quality-affecting work. 



\subsection{Simulant Preparation and Testing}

Simulants were developed to simulate the identified tank wastes at high risk for separable organics (241-C-106, 241-C-104, 241-AZ-101, 241-SY-102, and 241-AW-106). This simulant development work included appropriate document reviews and literature searches to identify the important components of non-radioactive waste simulant containing residual organics, and testing the constructed simulant(s) to ensure that the relevant characteristics of the wastes in the target tanks were replicated.

The compositions of these simulants reflect the sludge components and organic constituents found in the target tanks. These simulants have various amounts of organics (TBP, NPH, and D2EHPA) added to them.

\subsection{Simulant Preparation Procedure}

Each simulant was prepared beginning with an iron-rich sludge simulant based on tank AY-102/C-106 (Russell et al. 2009) with composition given in Table 3.1. This simulant base was chosen because it was already prepared and was close to the targeted tank compositions. This iron-rich sludge was spiked with the appropriate amounts of chemicals to obtain the targeted chemistry of each tank being simulated as shown in Table 3.2. Then supernate with composition determined by tank waste analysis in the Tank Waste Information Network System (TWINS) shown in Table 3.3 was added to the sludge to obtain the correct amount of supernate anions. The simulant supernate compositions are shown in Table 3.4.

Table 3.1. Composition of Iron-Rich Sludge Simulant Base

\begin{tabular}{lc|lc}
\hline \multicolumn{1}{c|}{ Chemical } & Mol Fraction & \multicolumn{1}{c}{ Chemical } & Mol Fraction \\
\hline $\mathrm{Ca}(\mathrm{OH})_{2}$ & 0.0237 & $\mathrm{Mg}(\mathrm{OH})_{2}$ & 0.0154 \\
$\mathrm{Ce}(\mathrm{OH})_{3}$ & 0.0035 & $\mathrm{Nd}(\mathrm{OH})_{3}$ & 0.0069 \\
$\mathrm{Fe}(\mathrm{OH})_{3}$ & 0.7324 & $\mathrm{Ni}(\mathrm{OH})_{2}$ & 0.0228 \\
$\mathrm{La}(\mathrm{OH})_{3}$ & 0.0026 & $\mathrm{Sr}(\mathrm{OH})_{2}$ & 0.0038 \\
$\mathrm{~Pb}(\mathrm{OH})_{2}$ & 0.0176 & $\mathrm{ZrO}(\mathrm{OH})_{2}$ & 0.0118 \\
$\mathrm{MnO}_{2}$ & 0.1595 & \multicolumn{3}{|c}{} \\
\cline { 2 - 3 } & \multicolumn{2}{|l}{}
\end{tabular}

Table 3.2. Amount of Iron-Rich Sludge, DIW, and Boehmite Added to Simulant Based on $2 \mathrm{~kg}$

\begin{tabular}{lccc}
\hline \multicolumn{1}{c}{ Simulant } & Iron Rich Sludge, g & DIW, g & AOH60 Boehmite, g \\
\hline Simulant A (C-106) & 719.1 & 891.9 & 158.7 \\
Simulant B (C-104) & 691.5 & 804.4 & 161.9 \\
Simulant C (AZ-101) & 844.0 & 541.5 & 144.6 \\
Simulant D (SY-102) & 1385 & 4.15 & 83.45 \\
Simulant E (AW-106) & 583.9 & 587.6 & 174.0 \\
\hline
\end{tabular}


Table 3.3. Composition of Supernate Simulants

\begin{tabular}{lccccc}
\hline Component & $\begin{array}{c}\text { Sim A } \\
\text { (C-106), g/L }\end{array}$ & $\begin{array}{c}\text { Sim B } \\
(\mathbf{C - 1 0 4 )}, \mathbf{g} / \mathbf{L}\end{array}$ & $\begin{array}{c}\text { Sim C } \\
(\mathbf{A Z - 1 0 1 )}, \mathbf{g} / \mathbf{L}\end{array}$ & $\begin{array}{c}\text { Sim D } \\
\text { (SY-102), g/L }\end{array}$ & $\begin{array}{c}\text { Sim E } \\
\text { (AW-106), g/L }\end{array}$ \\
\hline $\mathrm{OH}$ & 19 & 21 & 11.5 & 20 & 19 \\
$\mathrm{NO}_{3}$ & 0.50 & 16.9 & 71.1 & 107 & 168 \\
$\mathrm{NO}_{2}$ & 5 & 31.1 & 73.2 & 52.9 & 58.4 \\
$\mathrm{PO}_{4}$ & 3 & 2.8 & 1.5 & 3 & 2.5 \\
$\mathrm{SO}_{4}$ & 1.85 & 3.6 & 15 & 2 & 3.6 \\
$\mathrm{Cl}$ & 0.10 & 0.75 & 0.15 & 3.4 & 3.5 \\
$\mathrm{~F}$ & 0.05 & 9.6 & 2 & 0.12 & 1.2 \\
$\mathrm{Br}$ & 1 & 3 & 0.9 & 1.3 & 0.68 \\
$\mathrm{C}_{2} \mathrm{O}_{4}$ & 3.3 & 3.59 & 1 & 1 & 0.79 \\
$\mathrm{C}_{2} \mathrm{H}_{3} \mathrm{O}_{2}$ & 18.8 & 0.00 & 0.2 & 0.00 & 1 \\
\hline
\end{tabular}

Table 3.4. Recipe for Simulant Supernate Based on $2 \mathrm{~kg}$

\begin{tabular}{lccccc}
\hline \multicolumn{1}{c}{ Chemical } & $\begin{array}{c}\text { Simulant A } \\
\text { (C-106), g }\end{array}$ & $\begin{array}{c}\text { Simulant B } \\
(\mathbf{C - 1 0 4 )}, \mathbf{g}\end{array}$ & $\begin{array}{c}\text { Simulant C } \\
\text { (AZ-101), g }\end{array}$ & $\begin{array}{c}\text { Simulant D } \\
\text { (SY-102), g }\end{array}$ & $\begin{array}{c}\text { Simulant E } \\
\text { (AW-106), g }\end{array}$ \\
\hline $\mathrm{NaCl}$ & 0.1374 & 1.0052 & 0.1978 & 4.3788 & 4.3679 \\
$\mathrm{NaF}$ & 0.0921 & 17.25 & 3.5363 & 0.2107 & 2.0364 \\
$\mathrm{Na}_{2} \mathrm{SO}_{4}$ & 2.2796 & 4.3278 & 17.74 & 2.3104 & 4.0410 \\
$\mathrm{NaBr}$ & 1.0731 & 3.1408 & 0.9272 & 1.2827 & 0.6645 \\
$\mathrm{NaNO}_{3}$ & 0.5712 & 18.83 & 77.93 & 114.59 & 175.80 \\
$\mathrm{NaOH}(50 \%$ solution) & 74.48 & 80.31 & 43.27 & 73.50 & 68.22 \\
$\mathrm{Na}_{3} \mathrm{PO}_{4}$ & 4.3157 & 3.9297 & 2.0715 & 4.0459 & 3.2891 \\
$\mathrm{NaCH}_{3} \mathrm{COO}$ & 21.77 & 0.0000 & 0.2223 & 0.0000 & 1.0606 \\
$\mathrm{Na}_{2} \mathrm{C}_{2} \mathrm{O}_{4}$ & 4.1866 & 4.4435 & 1.2179 & 1.1894 & 0.9193 \\
$\mathrm{NaNO}_{2}$ & 6.2490 & 37.92 & 87.83 & 62.01 & 66.86 \\
\hline
\end{tabular}

\subsection{Organic Additions}

A baseline organic level was determined based on the average of the total organic carbon analysis in the TWINS data along with the TBP and dodecane data, if available, and is shown in Table 3.5. Using this baseline organic level (average), two organic levels (50\% and 25\% of the baseline) were prepared for each simulant, resulting in five different simulants with two different levels of organics added to each one. The $50 \%$ was added three times (with the last one being subsampled twice and run at two different centrifuge speeds) for a total of 20 samples tested as shown in Table 3.6. 
Table 3.5. Baseline Organic Composition

\begin{tabular}{|c|c|c|c|c|c|c|}
\hline Organic & $\begin{array}{c}\operatorname{Sim} A \\
(C-106), \\
\text { g/kg }\end{array}$ & $\begin{array}{c}\text { Sim B } \\
\text { (C-104), } \\
\text { g/kg }\end{array}$ & $\begin{array}{c}\text { Sim C } \\
\text { (AZ-101), } \\
\text { g/kg }\end{array}$ & $\begin{array}{c}\text { Sim D } \\
\text { (SY-102), } \\
\text { g/kg }\end{array}$ & $\begin{array}{c}\text { Sim E } \\
\text { (AW-106), } \\
\text { g/kg }\end{array}$ & $\begin{array}{c}\text { Average } \\
\text { Level, } \\
\text { g/kg }\end{array}$ \\
\hline TBP & 0.0102 & 3.72 & 0.0006 & 3.48 & 0.4762 & 1.54 \\
\hline Dodecane & 0.0237 & 5.31 & 0.0013 & 8.12 & 1.11 & 2.91 \\
\hline D2EHPA & 24.87 & 3.57 & 3.1282 & 11.60 & 1.81 & 9.00 \\
\hline Total & 24.90 & 12.60 & 3.13 & 23.20 & 3.40 & 13.45 \\
\hline
\end{tabular}

Table 3.6. Organic Separation Testing Matrix

\begin{tabular}{cccccc}
\hline $\begin{array}{c}\text { Organic } \\
\text { Level }\end{array}$ & $\begin{array}{c}\text { Sim A } \\
(\mathbf{C - 1 0 6})\end{array}$ & $\begin{array}{c}\text { Sim B } \\
\mathbf{( C - 1 0 4 )}\end{array}$ & $\begin{array}{c}\text { Sim C } \\
(\mathbf{A Z - 1 0 1 )}\end{array}$ & $\begin{array}{c}\text { Sim D } \\
\mathbf{( S Y - 1 0 2 )}\end{array}$ & $\begin{array}{c}\text { Sim E } \\
(\mathbf{A W - 1 0 6 )}\end{array}$ \\
\hline 1 & $25 \%$ & $25 \%$ & $25 \%$ & $25 \%$ & $25 \%$ \\
2A & $50 \%$ & $50 \%$ & $50 \%$ & $50 \%$ & $50 \%$ \\
2B & $50 \%$ & $50 \%$ & $50 \%$ & $50 \%$ & $50 \%$ \\
2C & $50 \%$ & $50 \%$ & $50 \%$ & $50 \%$ & $50 \%$ \\
\hline
\end{tabular}

\subsection{Testing Procedure}

In the initial set of tests, a sample of each simulant containing $25 \%$ organic and $50 \%$ organic was centrifuged at $4400 \mathrm{rpm}(\sim 4000 \mathrm{G})$ for 10 minutes and then inspected for an organic layer.

Then a sample of each simulant with $50 \%$ organic was placed in an oven at $50{ }^{\circ} \mathrm{C}$ for 7 days. Each day the samples were briefly removed from the oven ( $<5$ minutes) and shaken to thoroughly mix the simulant. After seven days, the samples were removed from the oven and centrifuged at $4400 \mathrm{rpm}$ ( $\sim 4000 \mathrm{G})$ for 10 minutes and then inspected for an organic layer.

Next a sample of each simulant was mixed and allowed to settle. After settling, the supernate was removed. Then the organics were added at $50 \%$ organic level to each simulant. The simulants were placed in the drying oven at $40^{\circ} \mathrm{C}$ for seven days. After seven days, they were removed from the oven and centrifuged at $4400 \mathrm{rpm}(4048 \mathrm{G}$ ) for 10 minutes and then inspected for an organic layer. Another sample of this simulant was also centrifuged at $2187 \mathrm{rpm}(1000 \mathrm{G})$ for 10 minutes and then inspected for an organic layer. 



\subsection{Test Results}

In the initial set of tests, both the $25 \%$ organic levels (“-1" tests) and 50\% organic levels (“-2A” tests) showed a layer of organic after centrifuging for 10 minutes at $4400 \mathrm{rpm}$, although some showed more than others, as shown in Figure 4.1 and Figure 4.2. Simulant A had just a slight amount of organic on top, with Simulants D and E having foam in the organic layer.

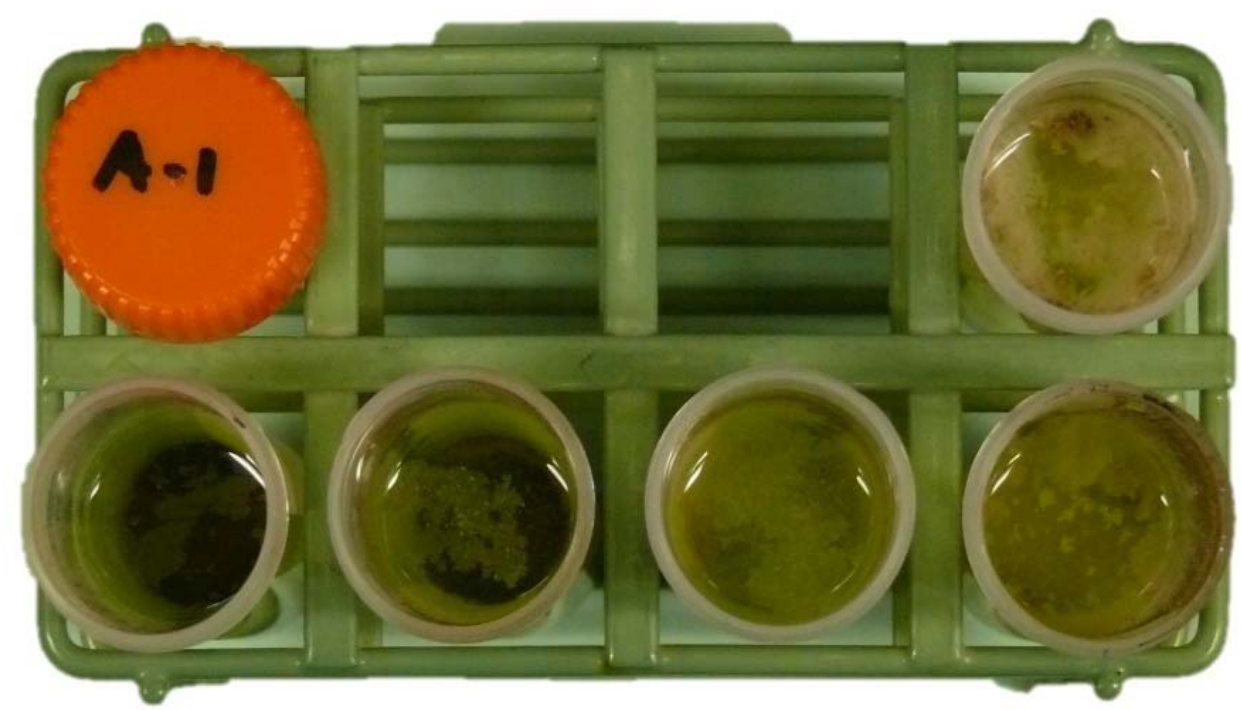

Figure 4.1. Samples with 25\% Organic Level (-1) (A-D left to right, with E above)

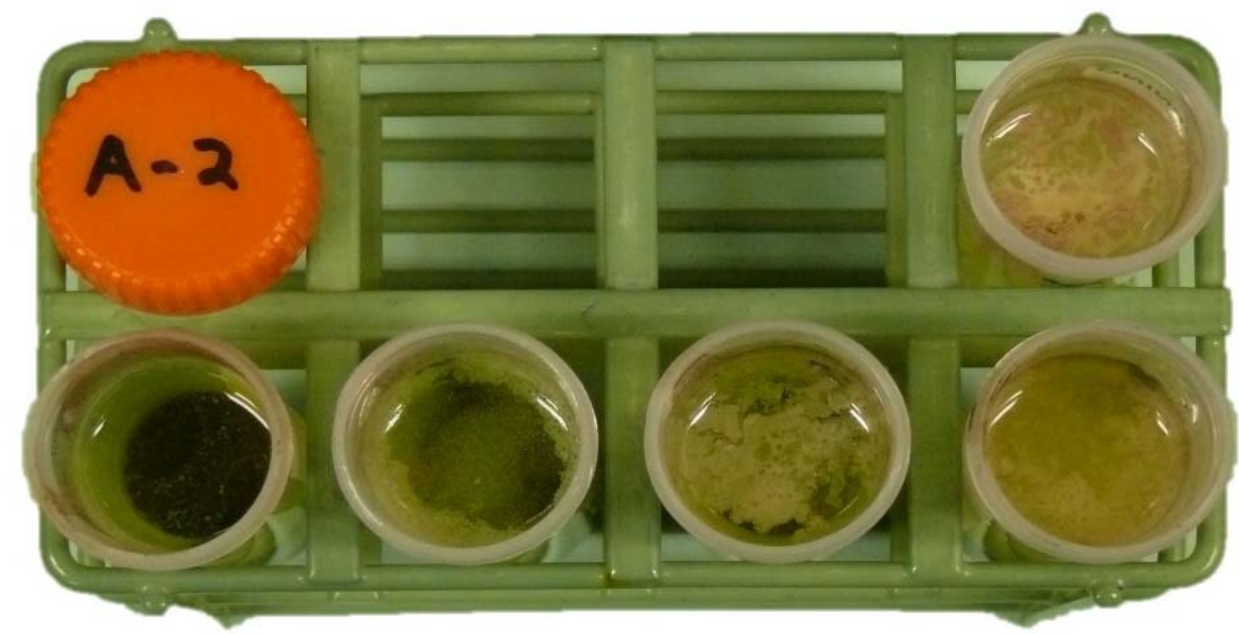

Figure 4.2. Samples with 50\% Organic Level (-2A) (A-D left to right, with E above)

In the next set of tests (-2B), after aging for seven days at $50{ }^{\circ} \mathrm{C}$ and being mixed once a day for $<5$ minutes, there was still a distinctive layer of organic on top after centrifuging at $4048 \mathrm{G}$ for 10 minutes, as shown in Figure 4.3. There wasn't any real difference in the aged samples (-2B) versus the initial samples with $50 \%$ of the organic level (-2A). 


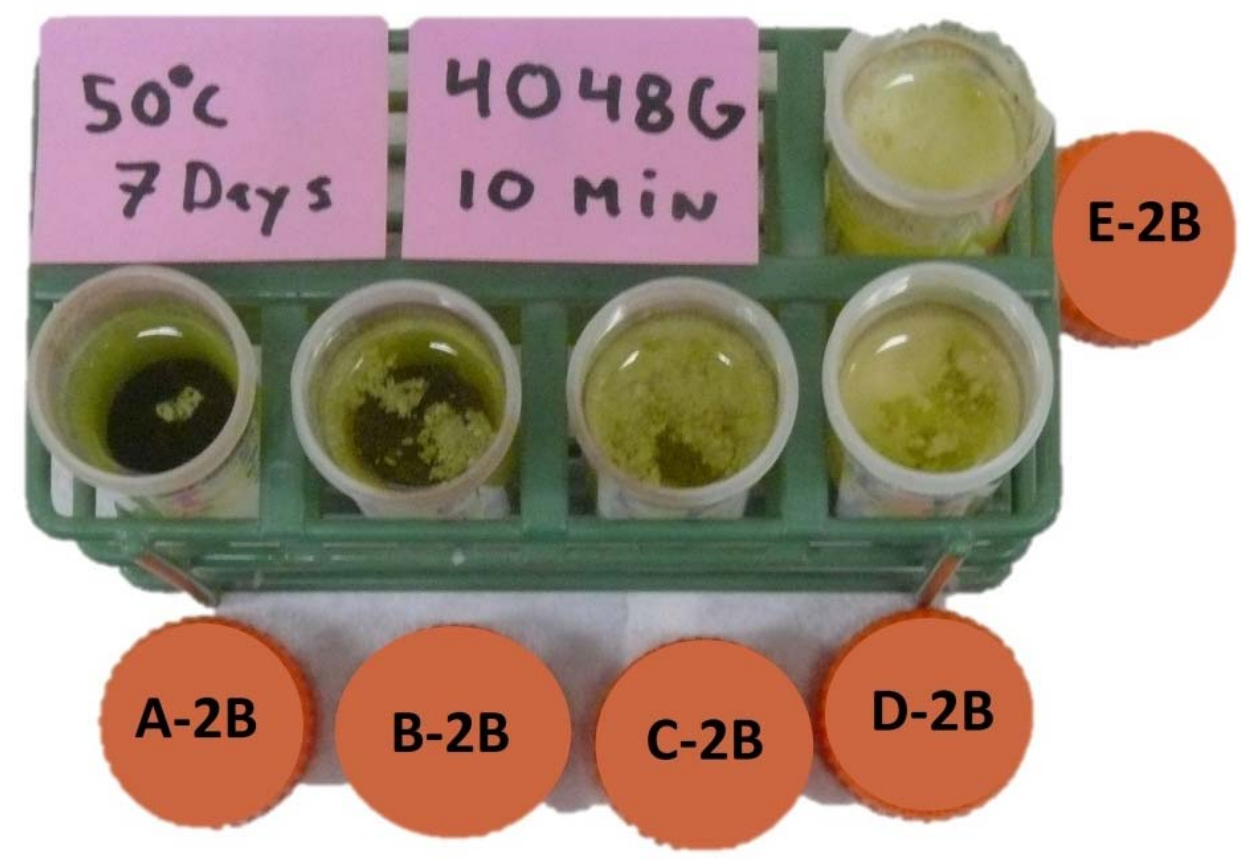

Figure 4.3. Samples with $50 \%$ Organic Level (-2B) Aged at $50{ }^{\circ} \mathrm{C}$ for 7 Days

Therefore, it was decided to remove the supernate from the simulant before adding the organic because in the Hanford waste tanks the supernate has been pumped off before the sludge is removed. So the simulant was removed as shown in Figure 4.4 after the simulant settled. The organic was then added to the simulant solids and aged at $40{ }^{\circ} \mathrm{C}$ for 7 days without being disturbed (-2C tests). After seven days, the samples were centrifuged at $4048 \mathrm{G}$ for 10 minutes and they all showed a layer of oganic, which wasn't appreciably different than the previous samples (Figure 4.5). These aged samples were subsampled again and run at $1000 \mathrm{G}$ for 10 minutes to determine if the strength of the centrifuge was making a difference in the organic separation. After centrifuging, they also showed an organic layer on top of the supernate (Figure 4.6).

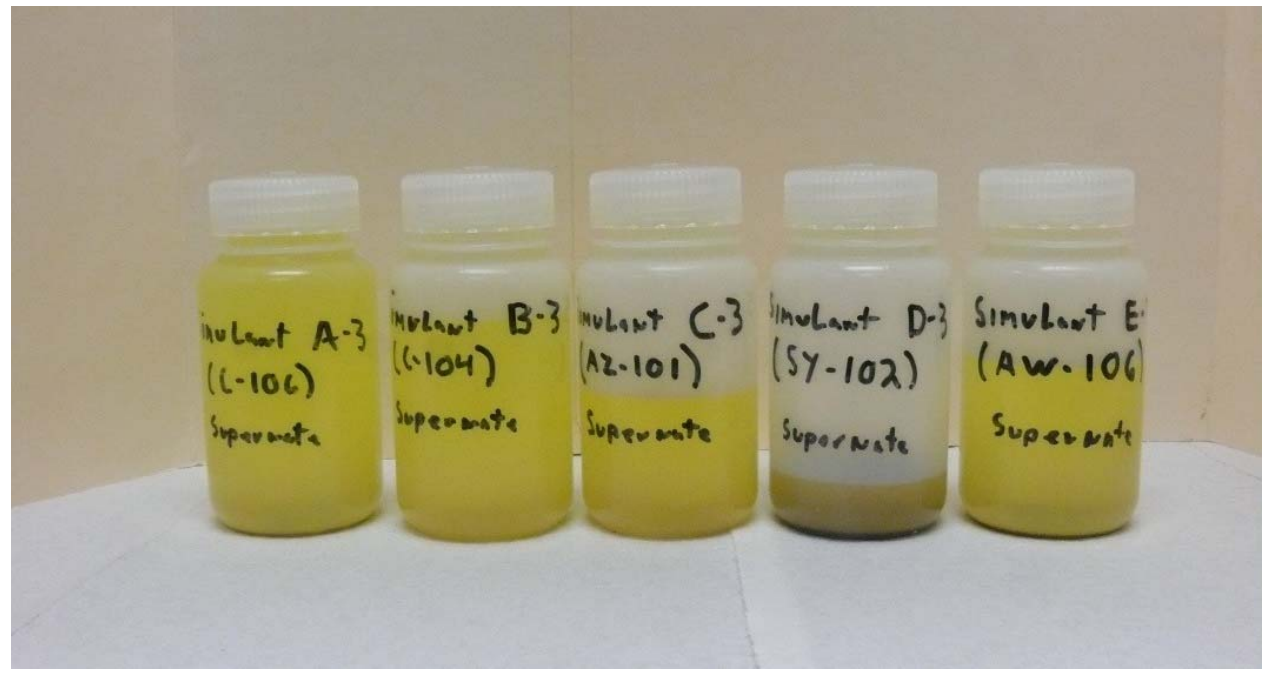

Figure 4.4. Supernate Removed from Simulant Before Organic Added and Aged 


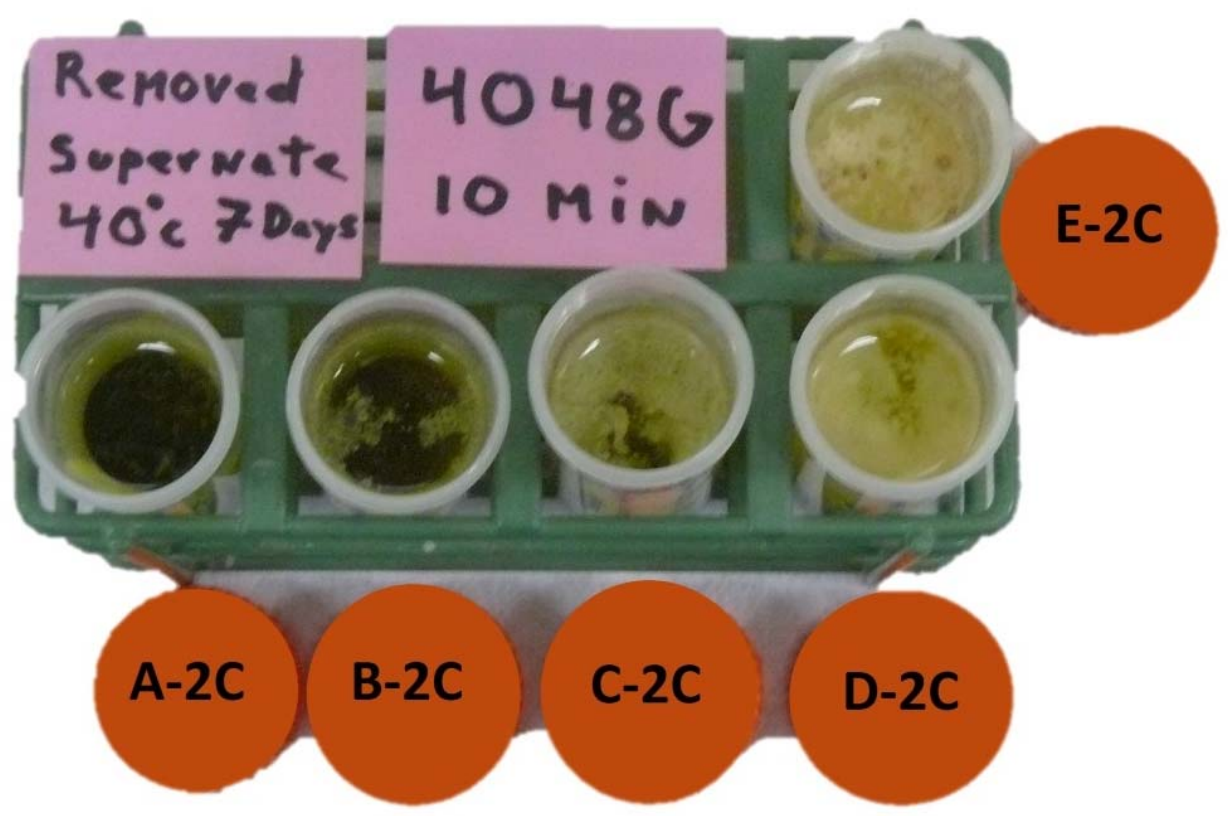

Figure 4.5. Samples with 50\% Organic Level and Supernate Removed (-2C) Aged at $40{ }^{\circ} \mathrm{C}$ for 7 Days and Centrifuged at $4048 \mathrm{G}$ for 10 Minutes

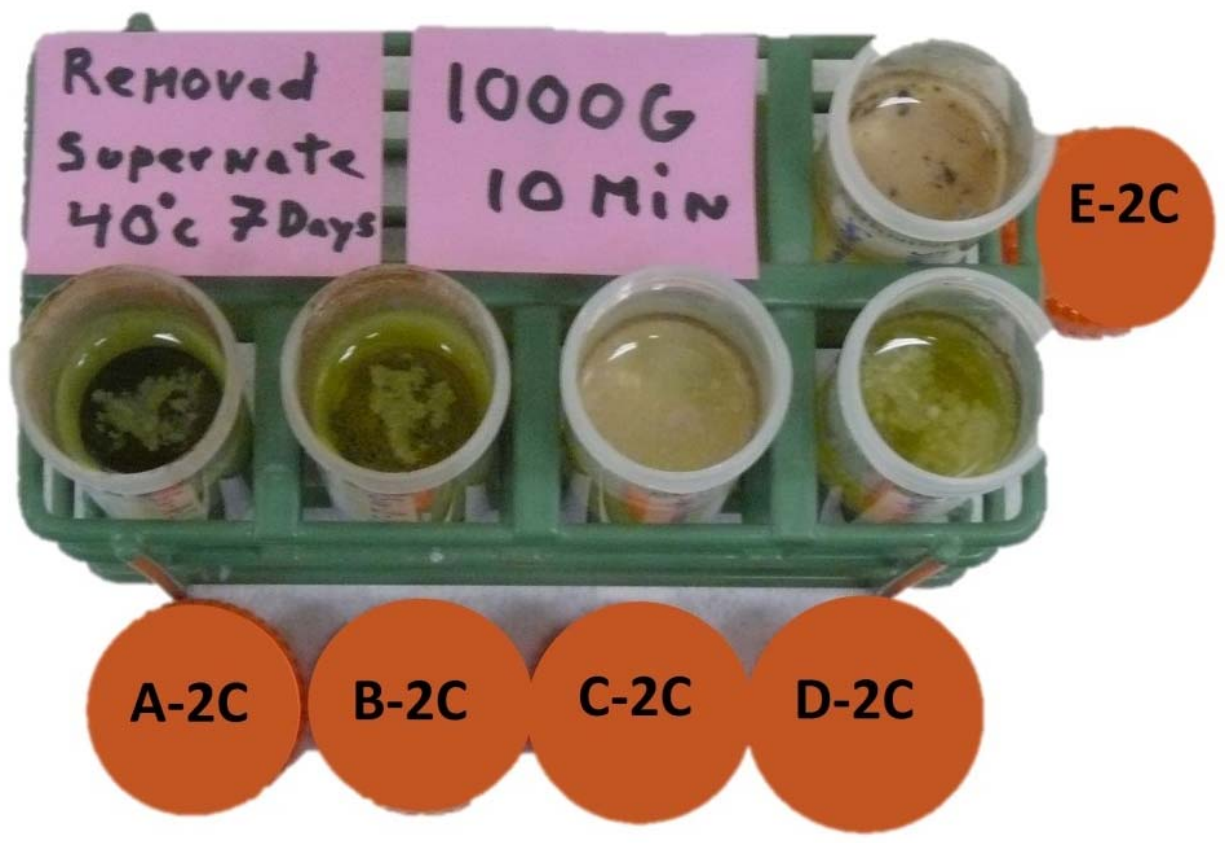

Figure 4.6. Samples with 50\% Organic Level and Supernate Removed (-2C) Aged at $40{ }^{\circ} \mathrm{C}$ for 7 Days and Centrifuged at $1000 \mathrm{G}$ for 10 Minutes

None of the conditions tested displayed a significant difference in the organic separation of any of the simulants tested; see Figure 4.7 as an example. In Figure 4.7, the samples are displayed in the order tested (50\% organic level at $4048 \mathrm{G}$; aged for 7 days at $50{ }^{\circ} \mathrm{C}$; supernate decanted, aged 7 days at $40{ }^{\circ} \mathrm{C}$; supernate decanted, aged 7 days at $40^{\circ} \mathrm{C}, 1000 \mathrm{G}$ ). The remaining tests are shown in Appendix A. In 
each set of tests, Simulant A displayed the least amount of separated organic with only a skiff in the center. Simulant B had slightly more but not enough to cover the entire top. Simulants C, D, and E, however, had significantly more separated organic and the entire top of the crucible was covered with some foam-like organic layer.

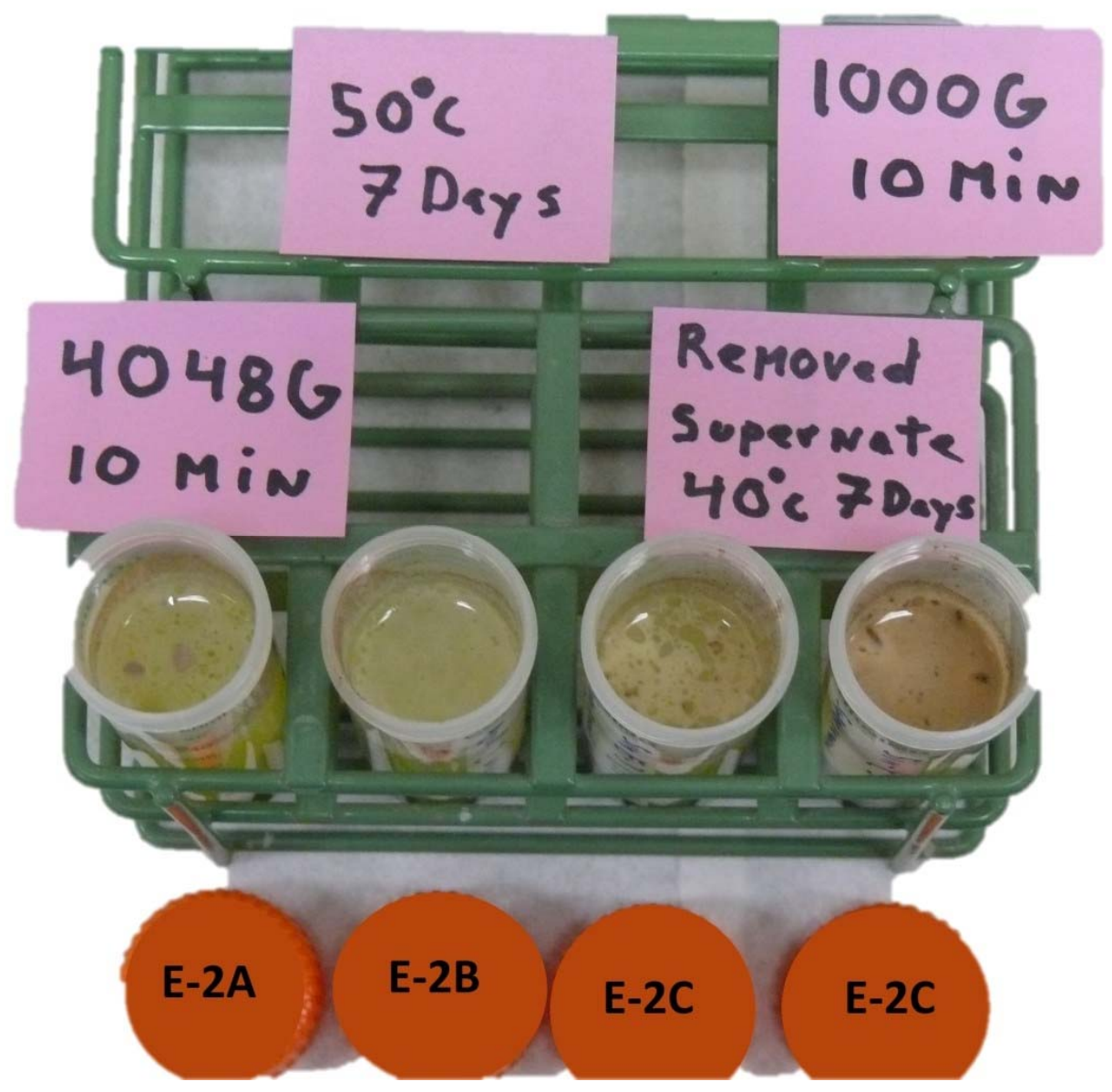

Figure 4.7. Each Set of Simulant E 50\% Organic Level Samples Compared in Order Run from Left to Right

It was also noticed that as the samples sat after centrifuging, in several of them at least part of the organic layer would settle to the top of the sludge layer in ball shapes as shown in Figure 4.8 for Simulant A. Because of this, Figure A.11 appears to show a larger organic layer in the Simulant A Aged Test 2C 1000 G than in the Simulant A Aged Test 2C 4048 G. However, the organic layer in the 4048 G sample had just settled. After re-centrifuging those two samples, the amount of organic separated was essentially the same, as shown in Figure 4.9. 


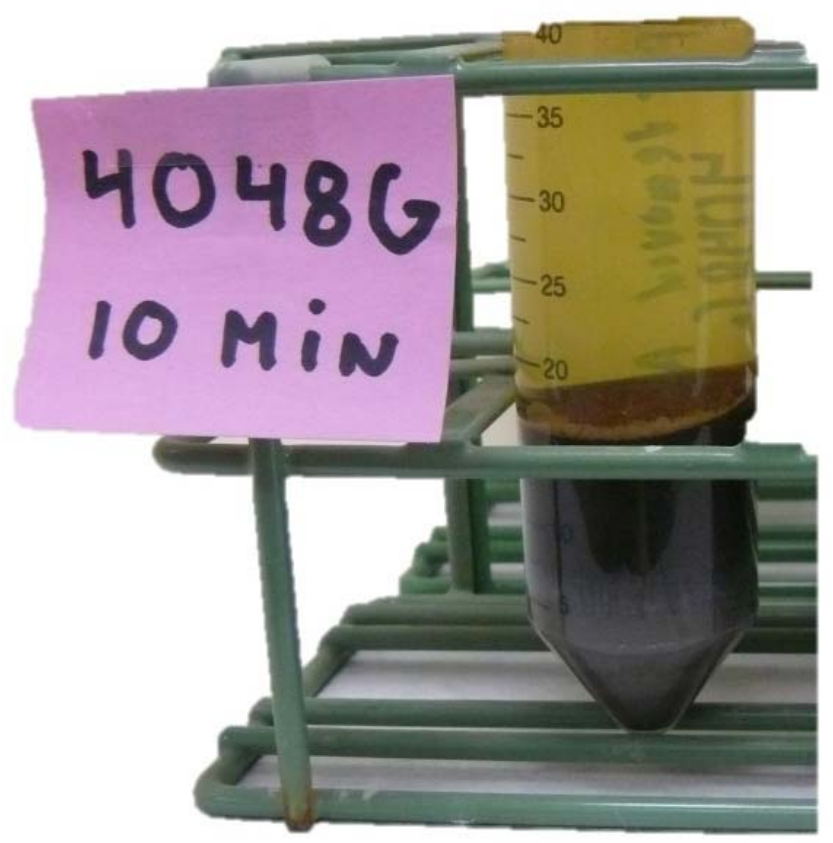

Figure 4.8. Simulant A (Test 2C) After Sitting for $\sim 3$ Weeks Showing Settled Organic Layer

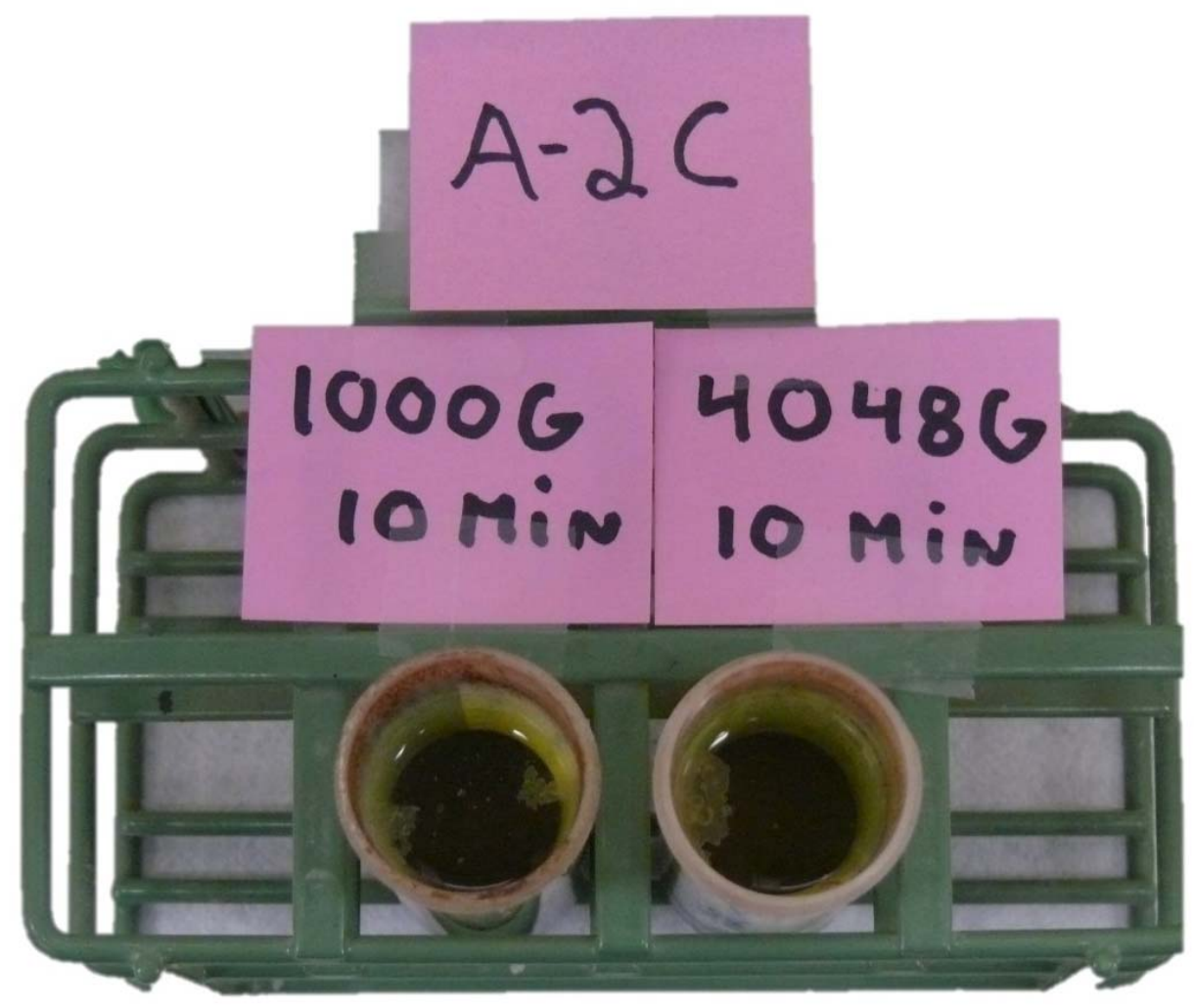

Figure 4.9. Simulant A Test 2C Freshly Centrifuged 



\subsection{Summary}

This study was intended to determine the best simulant to use for organic separation studies on a larger scale. Five different simulants were prepared and a sample of each simulant had $25 \%$ of the average organic level added to it and another sample of each simulant had $50 \%$ of the average organic level added. Each sample was centrifuged at $4048 \mathrm{G}$ for 10 minutes and they all showed a separated organic layer on the top of the supernate.

A sample of each simulant with $50 \%$ of the average organic level was then aged for 7 days at $50{ }^{\circ} \mathrm{C}$ with mixing once a day. After being centrifuged at $4048 \mathrm{G}$ for 10 minutes, they too all showed a separated organic layer on top of the supernate. A sample of each simulant was allowed to settle and the supernate was removed, then $50 \%$ of the average organic level was added and the samples were aged for 7 days at $40{ }^{\circ} \mathrm{C}$. Samples from these simulants were centrifuged at both $4048 \mathrm{G}$ and $1000 \mathrm{G}$ for 10 minutes and they all showed a separated organic layer on top of the supernate.

None of the conditions tested displayed a significant difference in the organic separation of each simulant. Simulant A was distinctively less separated than the other simulants under all scenarios and therefore would most likely be the best simulant to select if choosing one of these five to bind the organic phase. 



\subsection{References}

Russell RL, JM Billing, RA Peterson, DE Rinehart, and HD Smith. 2009. Development and

Demonstration of Ultrafiltration Simulants. PNNL-18090, Pacific Northwest National Laboratory, Richland, WA.

Smalley CS and VC Nguyen. 2013. One System Evaluation of Separable Organics in the Tank Waste. RPP-RPT-55646, Rev. 0, Washington River Protection Solutions, LLC, Richland, WA. 



\section{Appendix A}

\section{Simulant Pictures}





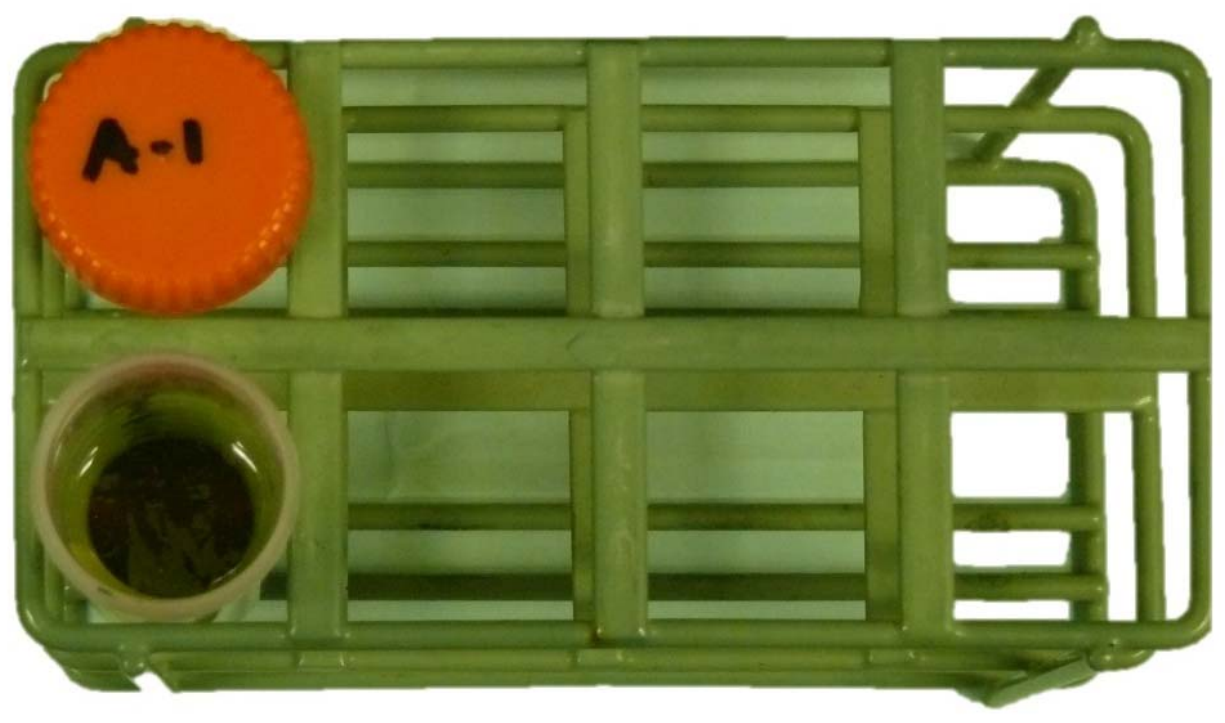

Figure A.1. Sample A-1 (Simulant A) with 25\% Organic Level

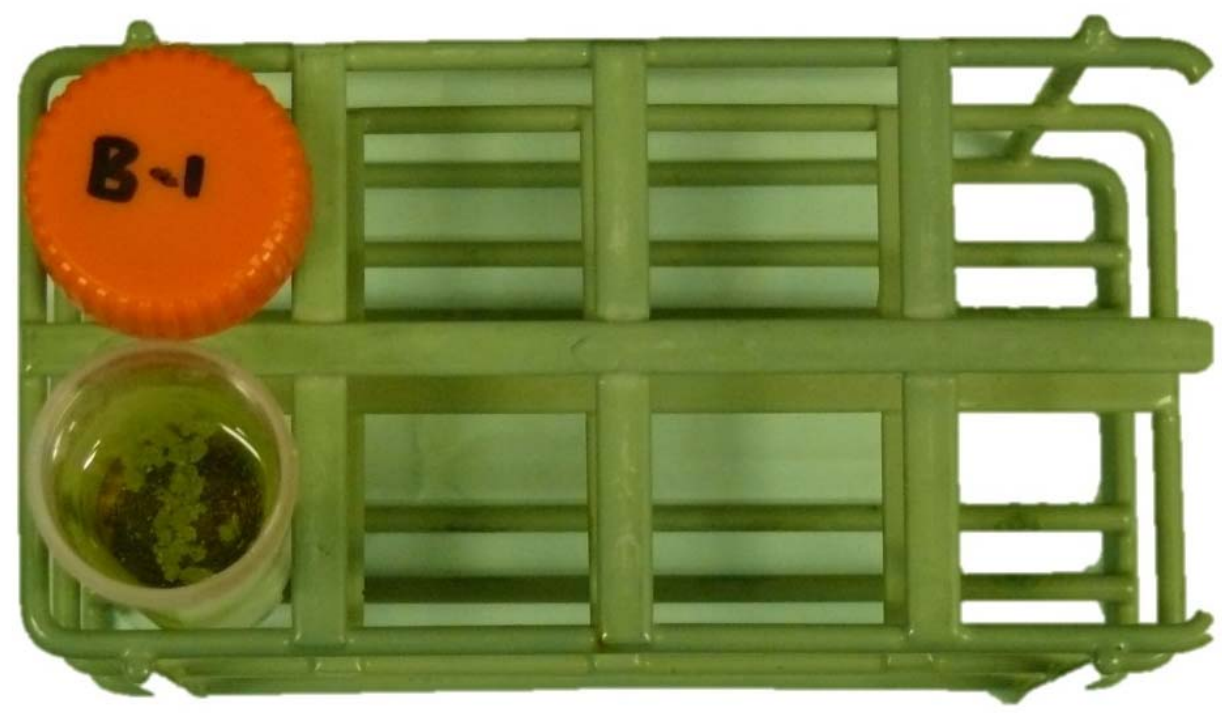

Figure A.2. Sample B-1 (Simulant B) with 25\% Organic Level 


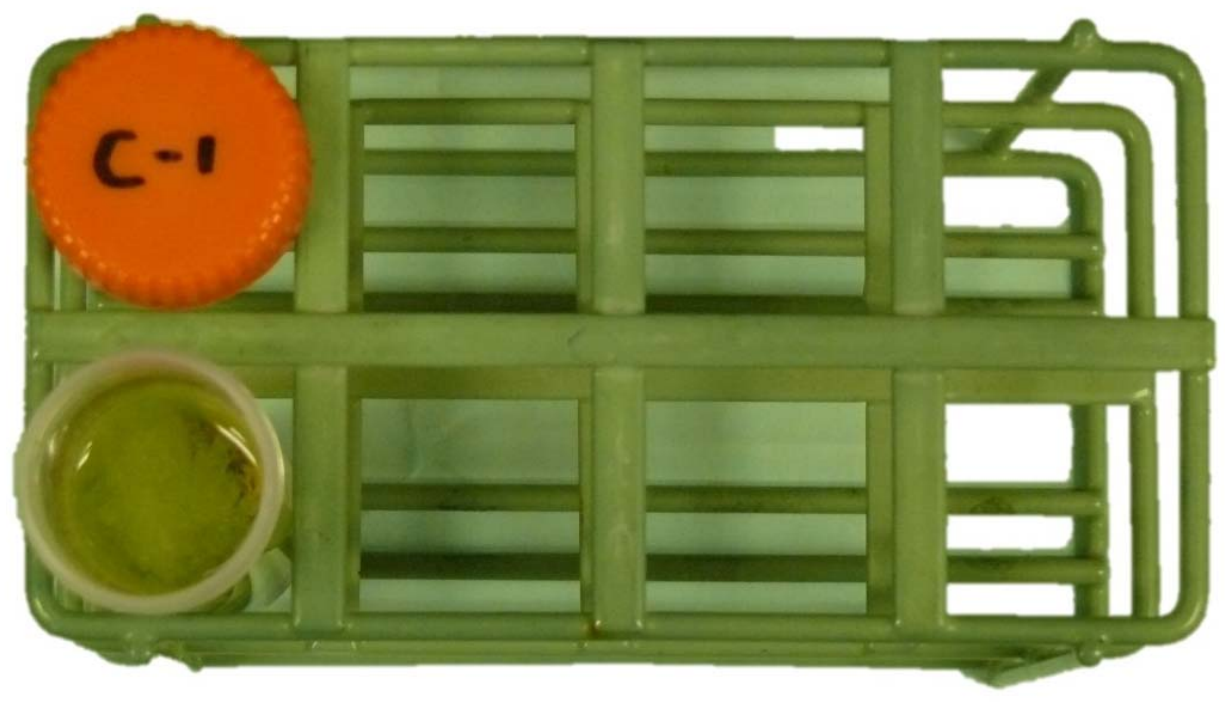

Figure A.3. Sample C-1 (Simulant C) with 25\% Organic Level

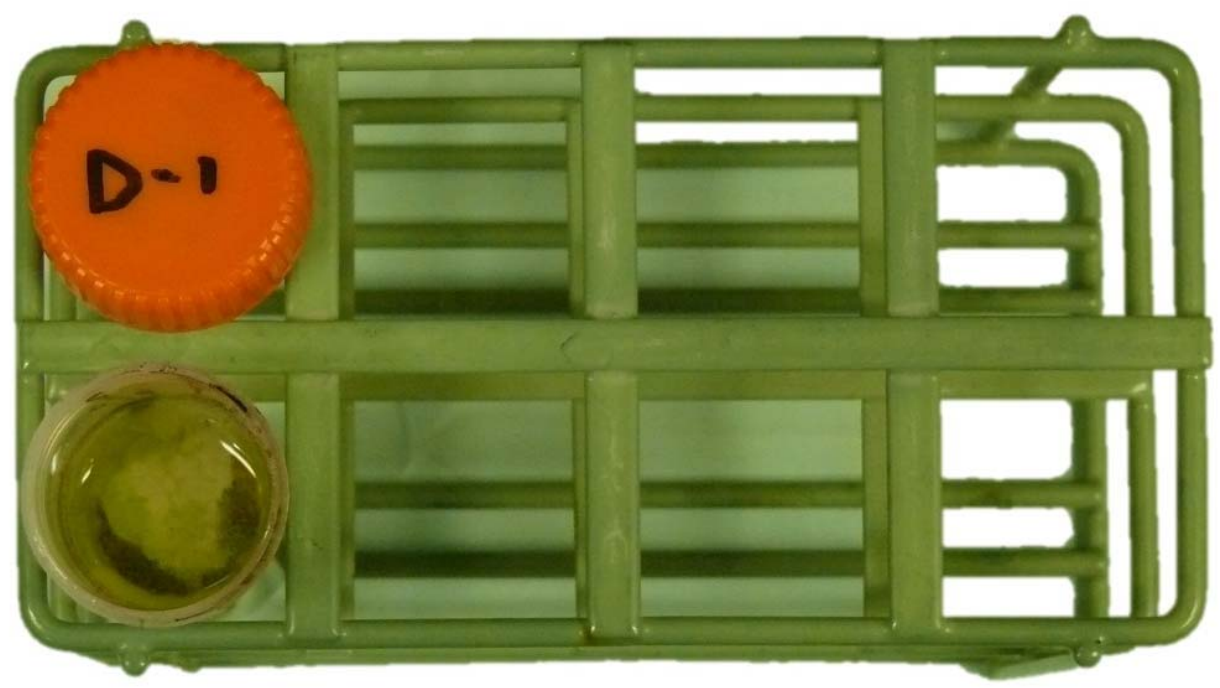

Figure A.4. Sample D-1 (Simulant D) with 25\% Organic Level 


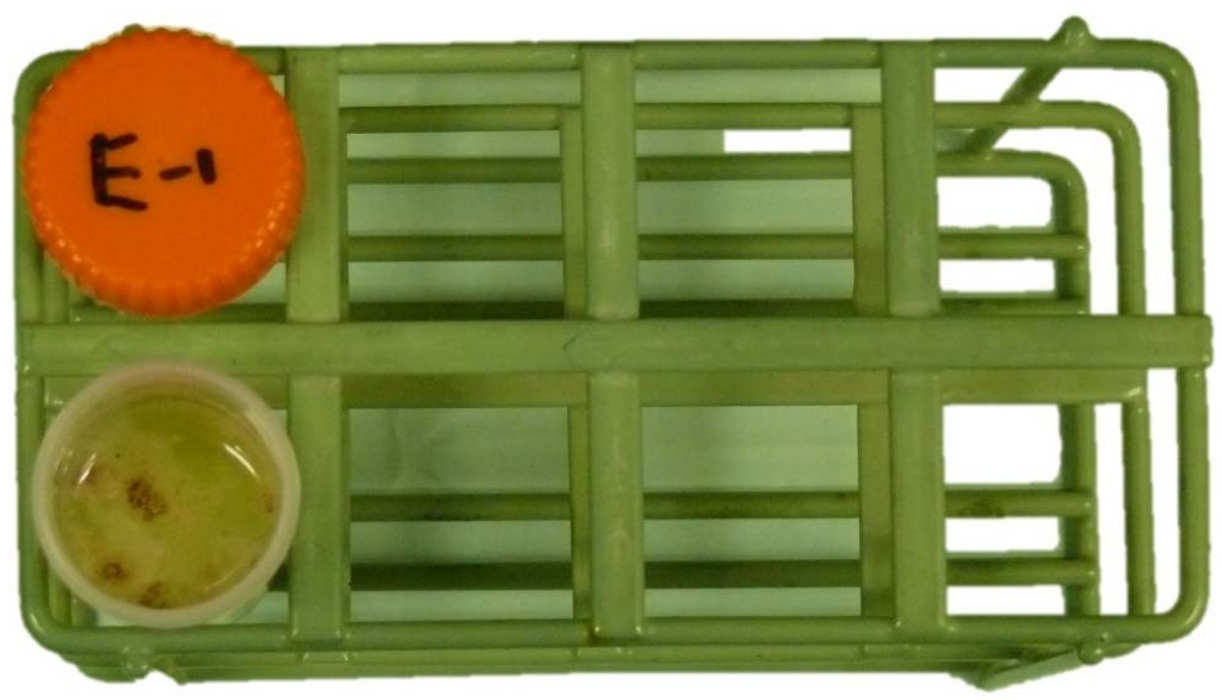

Figure A.5. Sample E-1 (Simulant E) with 25\% Organic Level

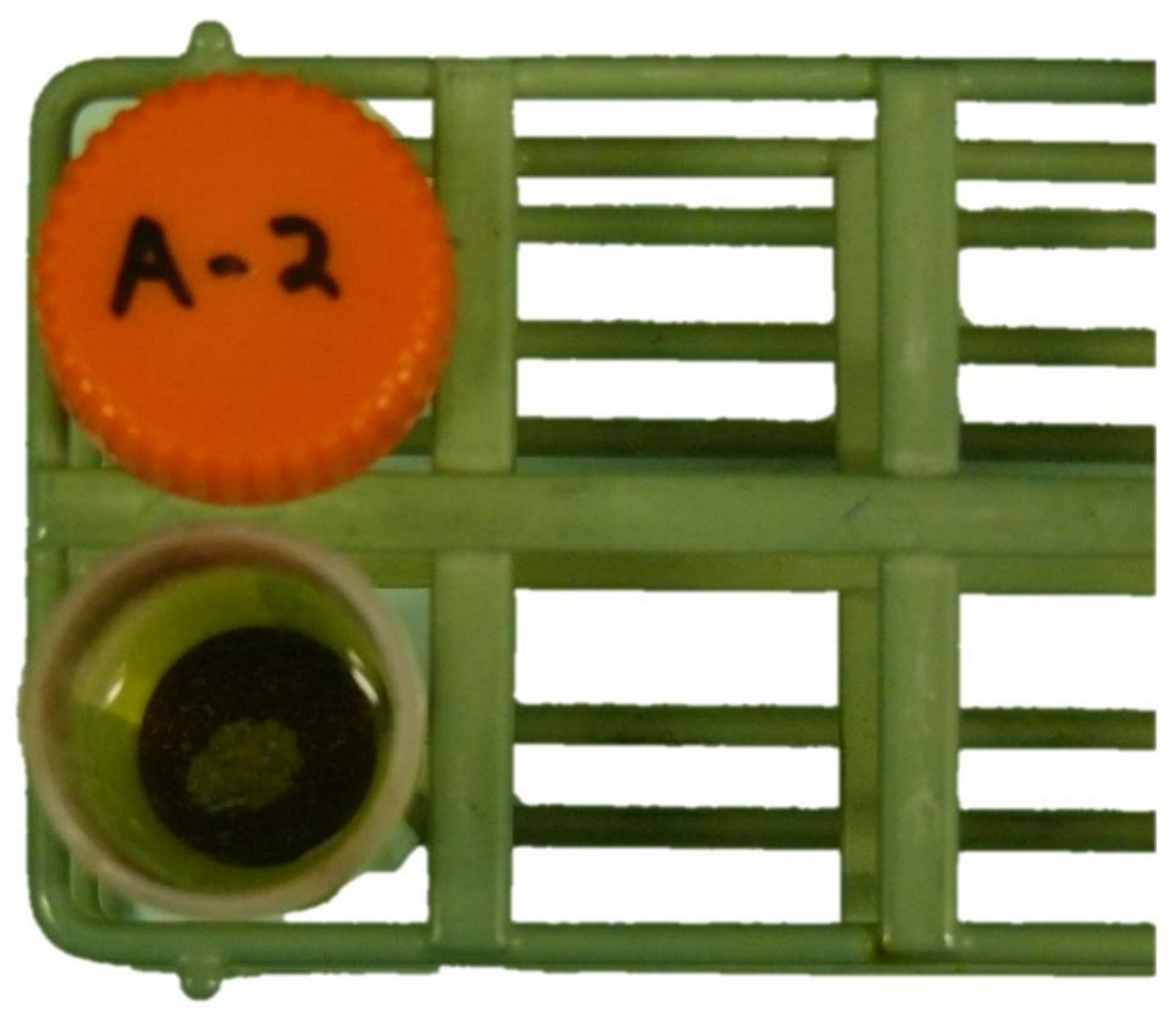

Figure A.6. Sample A-2A (Simulant A) with 50\% Organic Level 


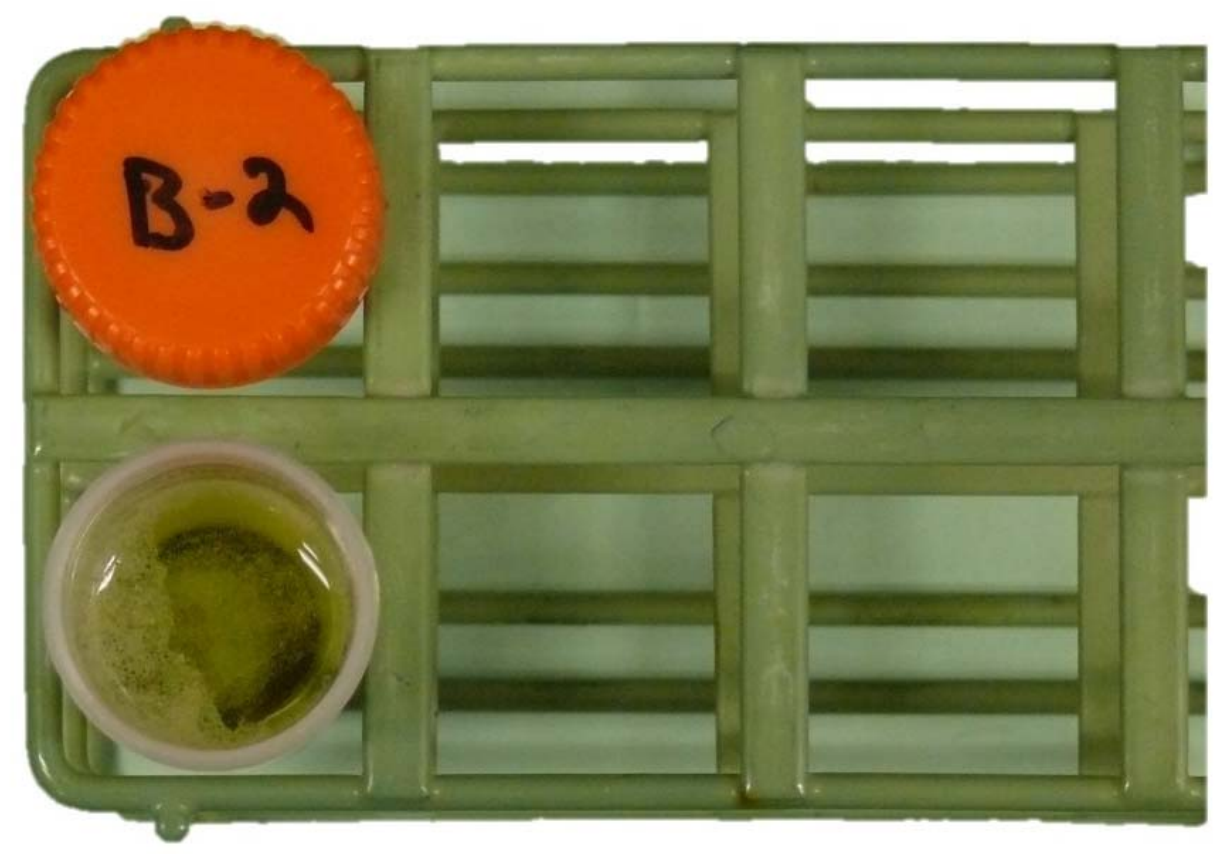

Figure A.7. Sample B-2A (Simulant B) with 50\% Organic Level

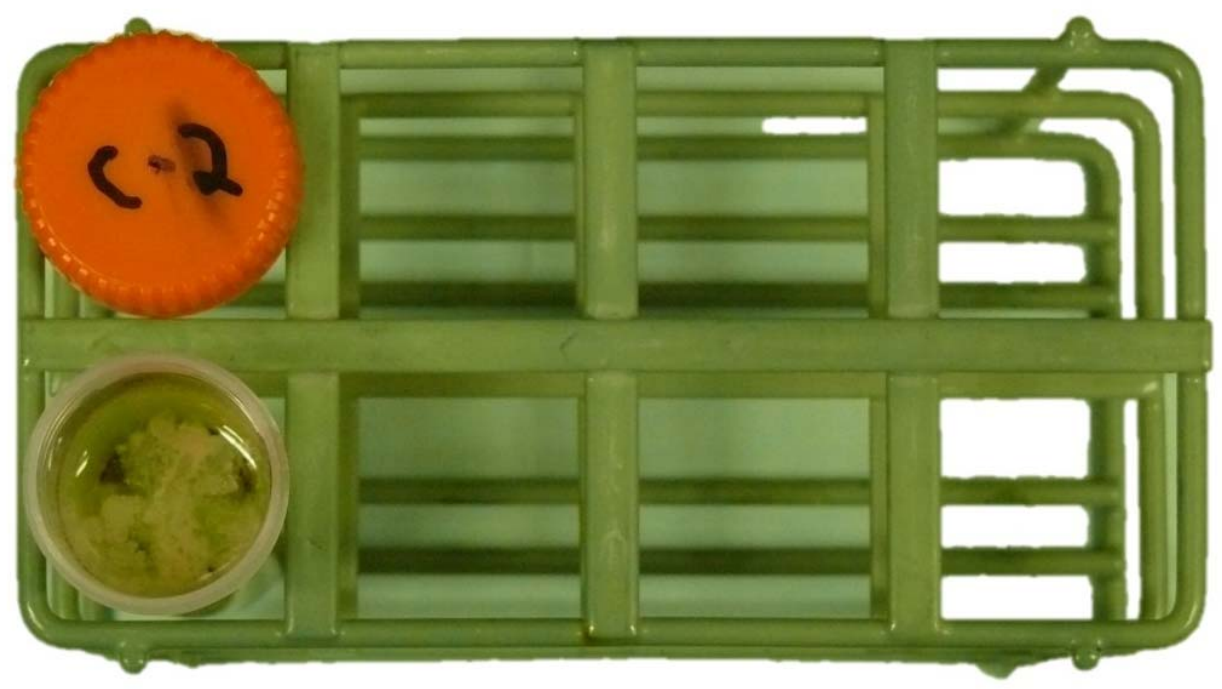

Figure A.8. Sample C-2A (Simulant C) with 50\% Organic Level 


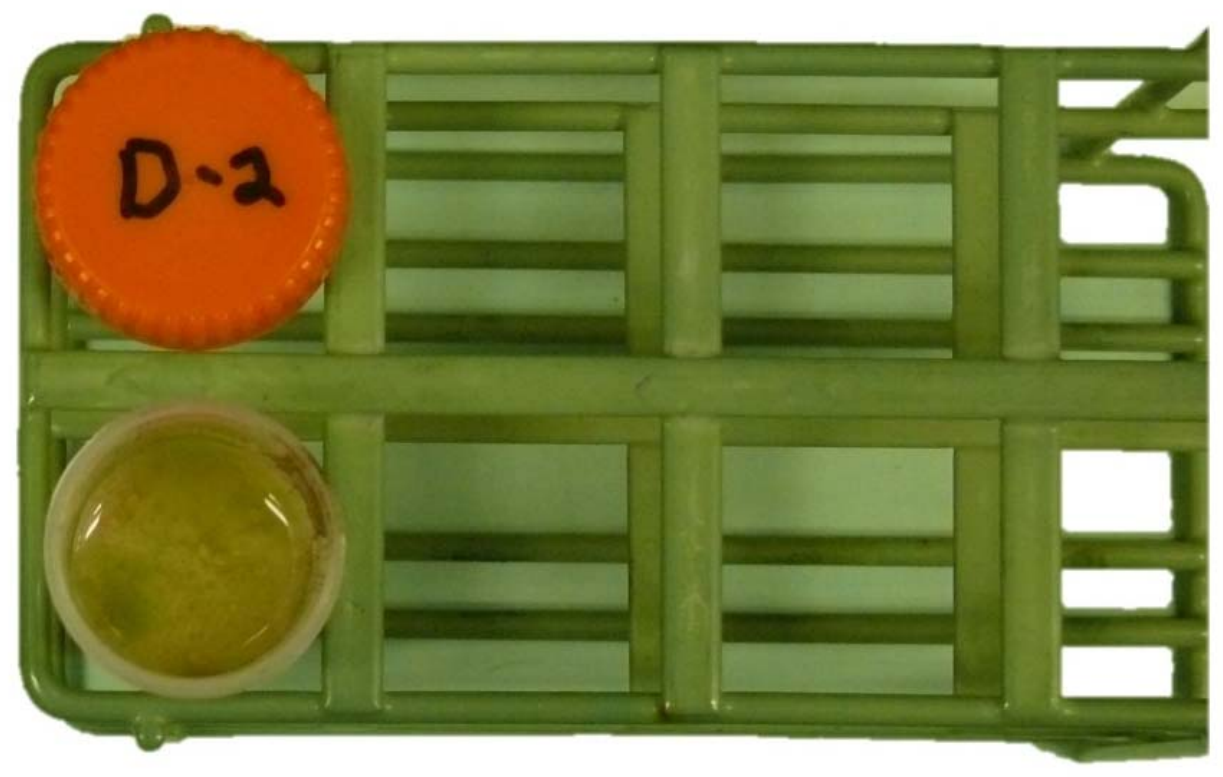

Figure A.9. Sample D-2A (Simulant D) with 50\% Organic Level

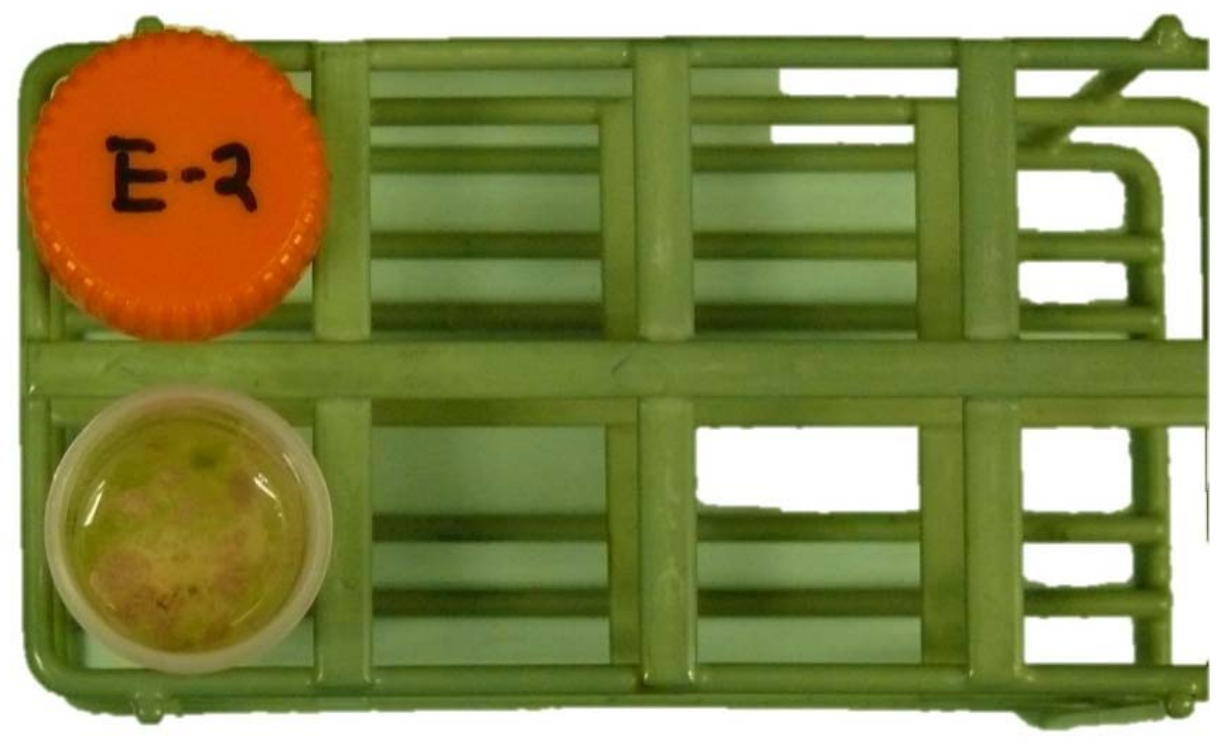

Figure A.10. Sample E-2A (Simulant E) with 50\% Organic Level 


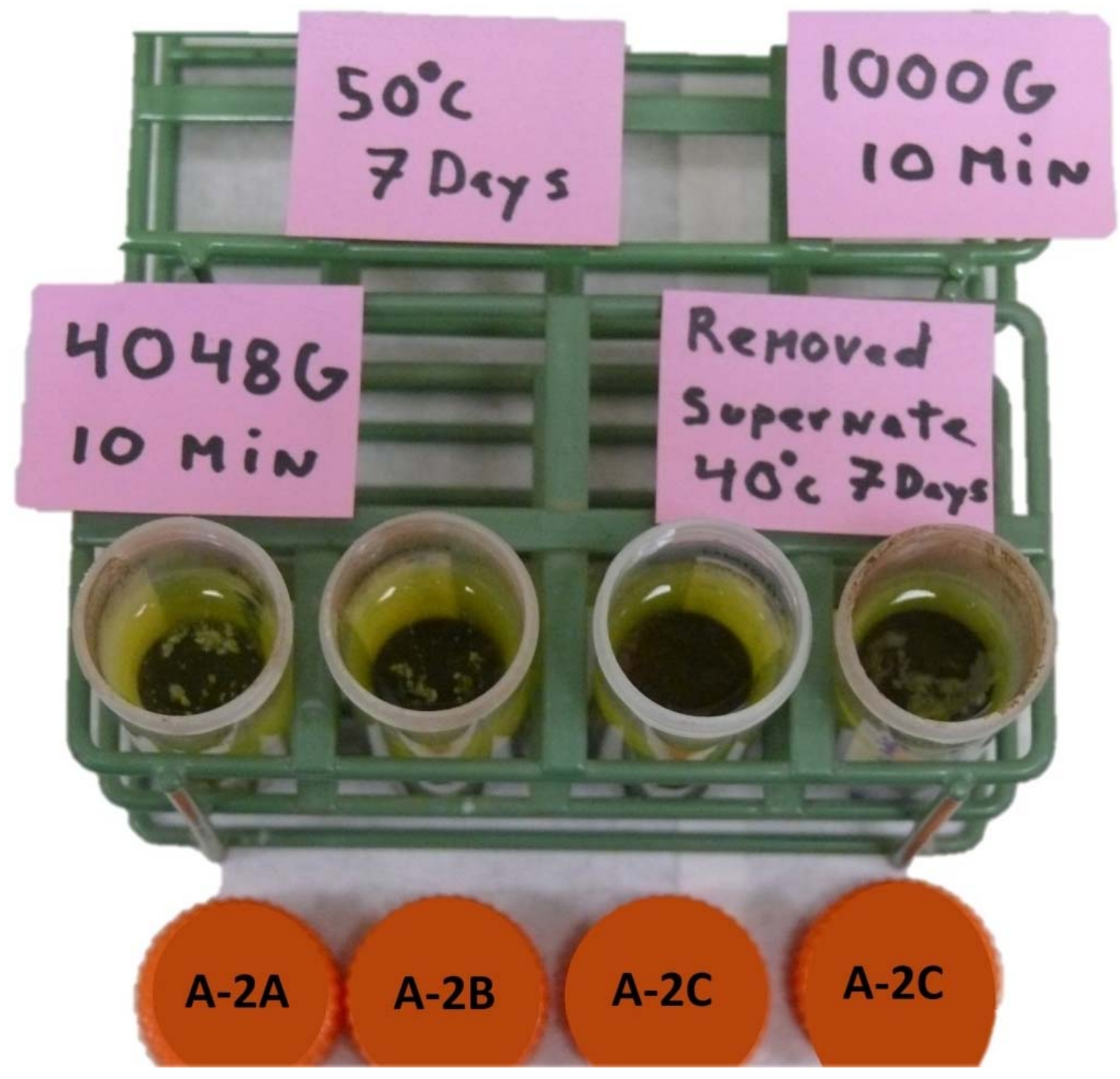

Figure A.11. Each Set of Simulant A 50\% Organic Level Samples Compared in Order Run from Left to Right 


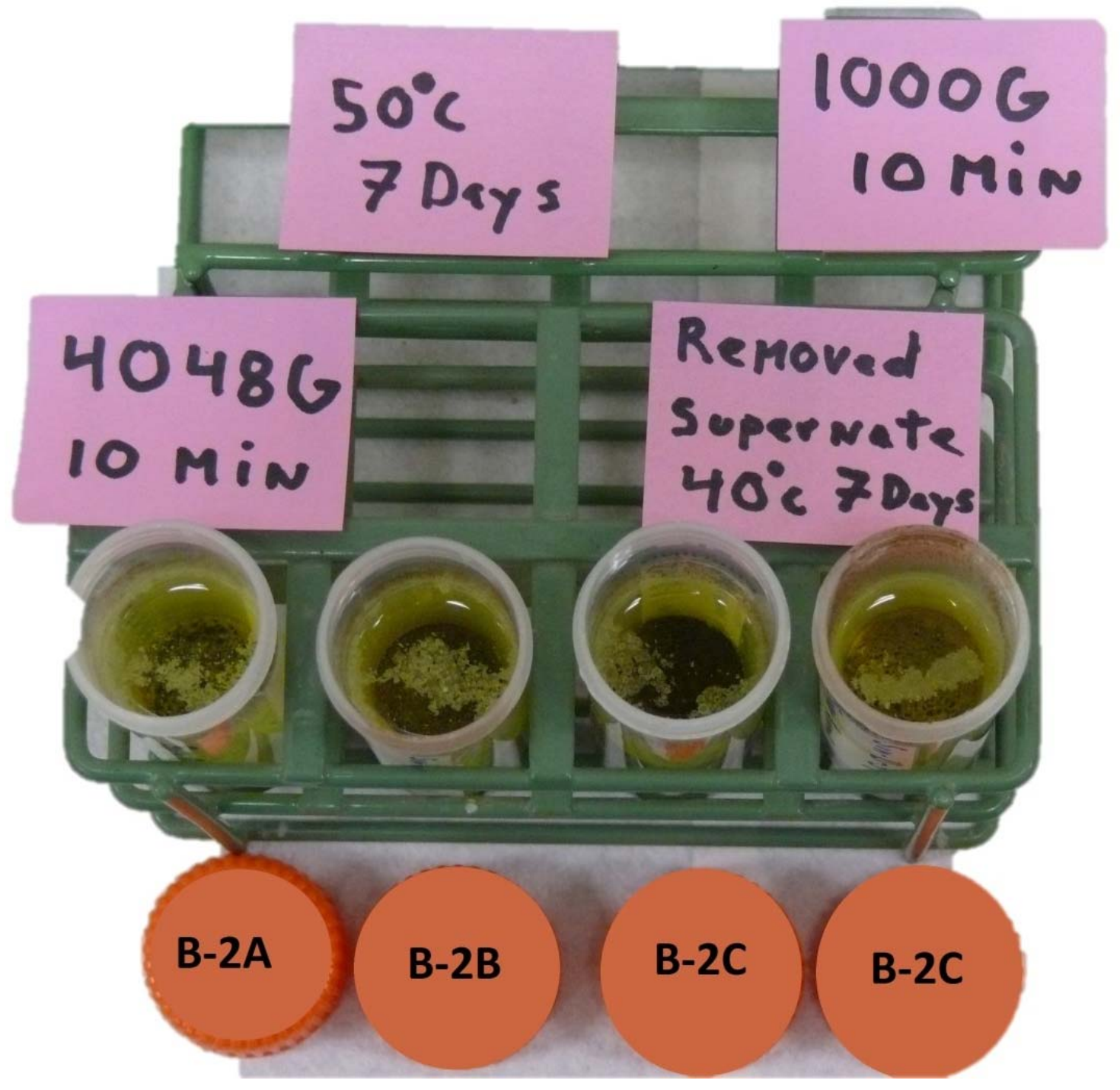

Figure A.12. Each Set of Simulant B 50\% Organic Level Samples Compared in Order Run from Left to Right 


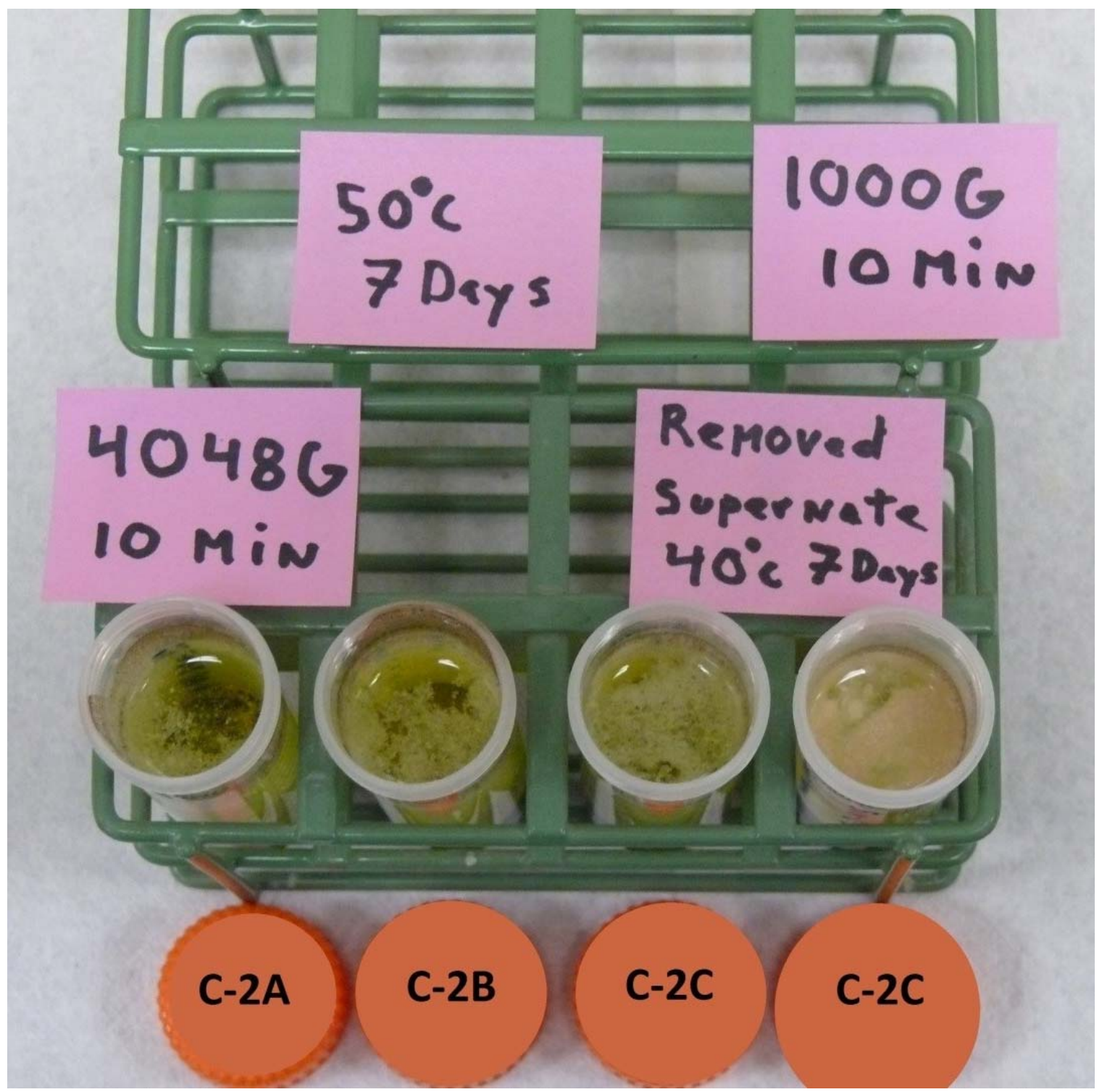

Figure A.13. Each Set of Simulant C 50\% Organic Level Samples Compared in Order Run from Left to Right 


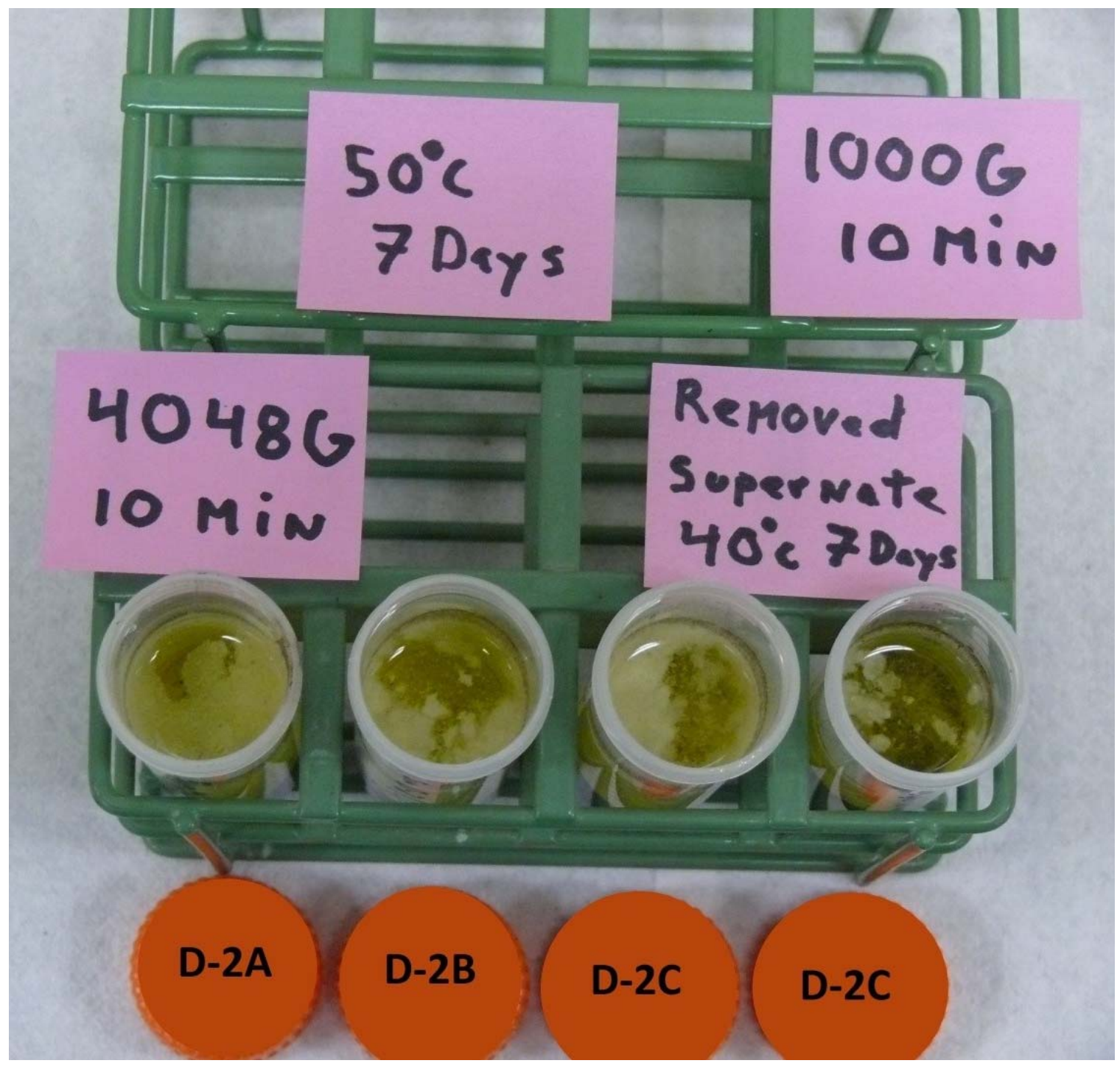

Figure A.14. Each Set of Simulant D 50\% Organic Level Samples Compared in Order Run from Left to Right 

PNNL-23643

RPT-66611-001, Rev. 0

\section{Distribution*}

U.S. Department of Energy Office of River Protection

JA Diediker

BJ Harp

CC Harrington

P Logan

BM Mauss

SH Pfaff

Washington River Protection Solutions

R Mabrouki

KM Sanders

D Shuford

KH Subramanian

DJ Swanberg

LE Thompson
Pacific Northwest National Laboratory

GN Brown

RA Peterson

DE Rinehart

RL Russell

S Schlahta

DM Wellman

Information Release (pdf)

*All distribution will be made electronically. 


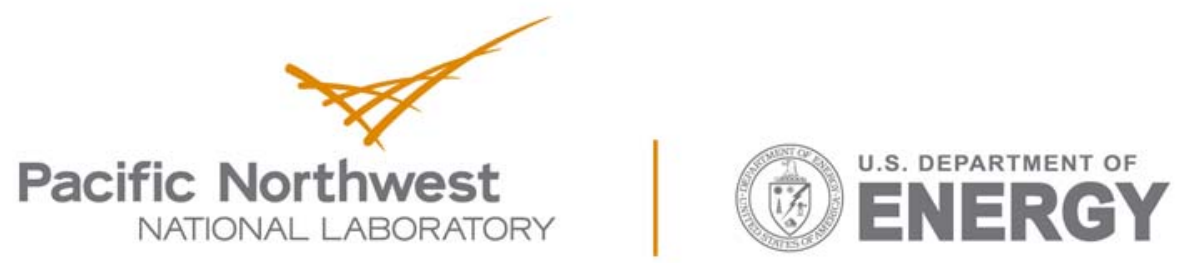

Proudly Operated by Battelle Since 1965

902 Battelle Boulevard

P.O. Box 999

Richland, WA 99352

1-888-375-PNNL (7665)

www.pnnl.gov 